\title{
LIST OF QUOTATIONS
}

Johannes Ludvicus Vives on the principles of conditioning. 1984, 41, 16.

Captain James Cook, behavior analyst. 1984, 42, 352.

Abigail Scott Duniway on aversion therapy for smoking and drinking. 1985, 43, 314.

Shakespeare on cogfitive behavior modification. $1985,43,320$.

James on self-control (with compliments to Bain). 1987, 47, 40.

Alexander Bain on the virtues of rule-governed behavior. 1987, 47, 96.

A. M. Turing on the parallel between learning and natural selection. 1987, 48, 96.

Wallace Craig on adjunctive behavior. 1987, 48, 250.

A. M. Turing on rule-governed and contingencyshaped computer learning programs. 1987, 48, 316.

Edgar Allan Poe on the extinction of neurotic fear by exposure with response prevention. 1988, 49, 48.

Samuel Johnson on nature and nurture. 1988, 50, 96.

Louisa May Alcott on extinction. 1988, 50, 272.

Joseph Addison on instinct. 1988, 50, 482.

Adam Gopnik on the role of variation and selection in art. 1989, 51, 46.

Ernest Hemingway: Under stimulus control in Paris. 1989, 51, 258.
On the token economy, 1846-style. 1989, 52, 110.

Faust on the priority of behavior. 1990, 53, 262.

Elementary, my dear Watson: A novel case of conditioned terror, from Oliver Wendell Holmes, Sr. 1990, 53, 304.

Reinforcers, punishers, changeover delays, and coca leaves. 1990, 54, 52.

The Chesnuts control a conversation. 1991, 55, 144.

DeMaupassant on stimulus control of aggression. 1991, 56, 238.

Bertrand Russell on discrimination training. 1992, 57, 32.

Montaigne on the use of punishment in education. 1992, 57, 176.

Montaigne on the Keller method. 1992, 57, 338.

W. Somerset Maugham on determinism. 1992, 58, 106.

Montaigne on respondent behavior. 1992, 58, 146.

John Steinbeck on theories. 1992, 58, 536.

T. H. Huxley and the importance of first principles. 1993, 59, 82.

Edwin Way Teale on shaping vulpine hunting skills. 1993, 59, 542.

Igor Stravinsky on the composer as locus. 1993, 60, 202.

Upton Sinclair on the development of phobias. 1993, $60,330$.

Stimulus overselectivity in the wild boy of Aveyron. 1993, 60, 414. 